Pesq. Vet. Bras. 37(11):1241-1246, novembro 2017 DOI: $10.1590 / \mathrm{S} 0100-736 \mathrm{X} 2017001100008$

\title{
Experimental poisoning by cassava wastewater in sheep ${ }^{1}$
}

\author{
Valdir C. Silva², Luciana A. de Oliveira ${ }^{4}$, Maira dos S.C. Lacerda ${ }^{2}$, Luciano A. \\ Pimentel $^{2}$, Wiles S. Santos ${ }^{2}$, Juliana Targino S.A. e Macêdo ${ }^{3}$, Franklin Riet-Correa ${ }^{5}$ \\ and Pedro M.O. Pedroso ${ }^{3 *}$
}

\begin{abstract}
Silva V.C., Oliveira L.A., Lacerda M.S.C., Pimentel L.A., Santos W.S., Macêdo J.T.S.A., Riet-Correa F. \& Pedroso P.M.O. 2017. Experimental poisoning by cassava wastewater in sheep. Pesquisa Veterinária Brasileira 37(11):1241-1246. Laboratório de Patologia Veterinária, Fundação Universidade de Brasília, Campus Universitário Darcy Ribeiro, Via L4 Norte s/n, Brasília, DF 70910-970, Brazil. E-mail: pedrosovet@yahoo.com.br

The processing of Manihot esculenta (cassava) tubers yield different by-products, including cassava wastewater, which is the liquid pressed out of the tuber after it has been mechanically crushed. Cyanide poisoning after ingestion of cassava wastewater has been reported in ruminants and pigs in Northeastern Brazil. With the aim of studying its toxicity, cassava wastewater was administered orally to six sheep at doses of $0.99,0.75,0.70$, 0.63 , and $0.5 \mathrm{mg}$ of hydrocyanic acid $\mathrm{kg}^{-1}$ body weight, which corresponded to $14.2,10.6$, $9.8,8.89$, and $7.1 \mathrm{~mL}$ of wastewater $\mathrm{kg}^{-1}$. On the second day, the sheep received a volume of wastewater which corresponded to $0.46,0.34,0.31,0.28$, and $0.23 \mathrm{mg}$ of $\mathrm{HCN} \mathrm{kg}^{-1}$. A sheep used as control received $9.9 \mathrm{~mL}_{\text {of }}$ water $\mathrm{kg}^{-1} \mathrm{BW}$. Sheep that received from 0.75 to $0.99 \mathrm{mg}$ $\mathrm{kg}^{-1}$ of HCN on the first day exhibited severe clinical signs of poisoning, and the sheep that received 0.63 and $0.5 \mathrm{mg} \mathrm{kg}^{-1}$ exhibited mild clinical signs. All sheep were successfully treated with sodium thiosulfate. On the second day, only the sheep that received $0.46 \mathrm{mg} \mathrm{kg}^{-1}$ and $0.34 \mathrm{mg} \mathrm{kg}^{-1}$ exhibited mild clinical signs and recovered spontaneously. The concentration of $\mathrm{HCN}$ in the wastewater was $71.69 \pm 2.19 \mu \mathrm{g} \mathrm{mL}^{-1}$ immediately after production, $30.56 \pm 2.45$ $\mu \mathrm{g} \mathrm{mL}{ }^{-1}$ after 24 hours, and $24.25 \pm 1.28 \mu \mathrm{g} \mathrm{mL}^{-1}$ after 48 hours. The picric acid paper test was strongly positive 5 minutes after production; moderately positive 24 hours after production, and negative 48 hours after production. We conclude that cassava wastewater is highly toxic to sheep if ingested immediately after production, but rapidly loses toxicity in 24-48 hours.
\end{abstract}

INDEX TERMS: Cassava, wastewater, hydrocyanic acid, sheep, ruminant, northeastern Brazil.

RESUMO.- [Intoxicação experimental por manipueira em ovinos.] 0 processamento dos tubérculos de Manihot esculenta (mandioca) produzem diferentes subprodutos, incluindo a manipueira, líquido que escorre das raízes da

\footnotetext{
${ }^{1}$ Received on November 23, 2016.

Accepted for publication on March 17, 2017.

${ }^{2}$ Setor de Patologia Veterinária, Hospital Universitário de Medicina Veterinária, Universidade Federal do Recôncavo da Bahia (UFRB), Rua Rui Barbosa 710, Campus Universitário, Cruz das Almas, BA 44380-000, Brazil.

${ }^{3}$ Laboratório de Patologia Veterinária, Fundação Universidade de Brasília (UnB), Campus Universitário Darcy Ribeiro, Via L4 Norte s/n, Brasília, DF 70910-970, Brazil. *Coresponding author: pedrosovet@yahoo.com.br

${ }^{4}$ Embrapa Mandioca e Fruticultura, Rua Embrapa s/n, Cruz das Almas, BA 44380-000, Brazil.

${ }^{5}$ National Institute of Agricultural Research (INIA), Colonia del Sacramento, Casilla de Correo 39173, Colonia, 70000, CP 70.000, Uruguay.
}

mandioca depois de ter sido mecanicamente prensada. A intoxicação por cianeto após a ingestão de manipueira tem sido relatada em ruminantes e suínos no Nordeste do Brasil. Com o objetivo de estudar sua toxicidade, administrou-se manipueira por via oral a seis ovelhas em doses de $0,99,0,75,0,70,0,63$ e 0,5 mg de peso corporal de ácido cianídrico $\mathrm{kg}^{-1}$, correspondendo a 14,2, 10,6, 9,8, 8,89 e 7,1 $\mathrm{mL}$ de manipueira $\mathrm{kg}^{-1}$ de peso corporal. No segundo dia, as ovelhas receberam um volume de manipueira que correspondeu a $0,46,0,34,0,31,0,28$ e $0,23 \mathrm{mg} \mathrm{de} \mathrm{HCN} \mathrm{kg}^{-1}$. Uma ovelha usada como controle recebeu 9,9 mL de água $\mathrm{kg}^{-1}$ de peso corporal. Ovelhas que receberam doses de 0,75 a $0,99 \mathrm{mg} \mathrm{kg}^{-1}$ de HCN no primeiro dia exibiram sinais clínicos graves de intoxicação e as ovelhas que receberam 0,63 e $0,5 \mathrm{mg} \mathrm{kg}^{-1}$ exibiram sinais clínicos leves. Todas as ovelhas foram tratadas com sucesso com tiossulfato de sódio. 
No segundo dia, apenas as ovelhas que receberam $0,46 \mathrm{mg}$ $\mathrm{kg}^{-1}$ e $0,34 \mathrm{mg} \mathrm{kg}^{-1}$ apresentaram sinais clínicos leves e se recuperaram espontaneamente. A concentração de HCN na manipueira foi de $71,69 \pm 2,19 \mu \mathrm{g} \mathrm{mL}^{-1}$ imediatamente após a produção, 30,56 $\pm 2,45 \mu \mathrm{g} \mathrm{mL}{ }^{-1}$ após 24 horas e $24,25 \pm$ $1,28 \mu \mathrm{g} \mathrm{mL}^{-1}$ após 48 horas. 0 teste de papel picrosódico foi fortemente positivo 5 minutos após a produção; moderadamente positivo 24 horas após a produção e negativo 48 horas após a produção. Concluímos que a manipueira é altamente tóxica para ovinos se ingeridas imediatamente após a produção, mas rapidamente perdem toxicidade em 24-48 horas.

TERMOS DE INDEXAÇÃO: Mandioca, manipueira, ácido cianídrico, ovinios, ruminante, Nordeste do Brasil.

\section{INTRODUCTION}

Manihot esculenta Crantz (cassava) is a cyanogenic plant which tuber roots are used to produce flour or starch. The processing of the tubers yield different by-products including wastewater, which is the liquid pressed out of the tuber after it has been mechanically crushed (Cereda 2001). In Brazil, cassava wastewater has been used as animal food (Almeida et al. 2009). It is also recommended as fertilizer (Ferreira et al. 2001). However, in most cases, the wastewater is disposed into the environment causing pollution or animal poisoning (Fig.1). In a recent study carried out by our research group, cassava wastewater was mentioned by 27 out of 67 farmers as the main cause of animal poisoning in the region and affected cattle, sheep, donkeys, pigs, and chicken (Pinheiro et al. 2013). Usually, poisoning occurs when the wastewater is discharged through pipes or channels to containers or areas to which animals have free access. The cassava varieties used in northeastern Brazil for flour production are the bitter varieties with roots containing $0.02-0.03 \%$ HCN (DM basis) (Murugesrawi et al. 2006). The cyanogenic glycosides contained in cassava are linamarin (approx. 95\%) and lotaustralin (5\%). Through processing, linamarase comes in contact with cyanogenic glycosides and catalyzes the hydrolysis to glucose and cya-

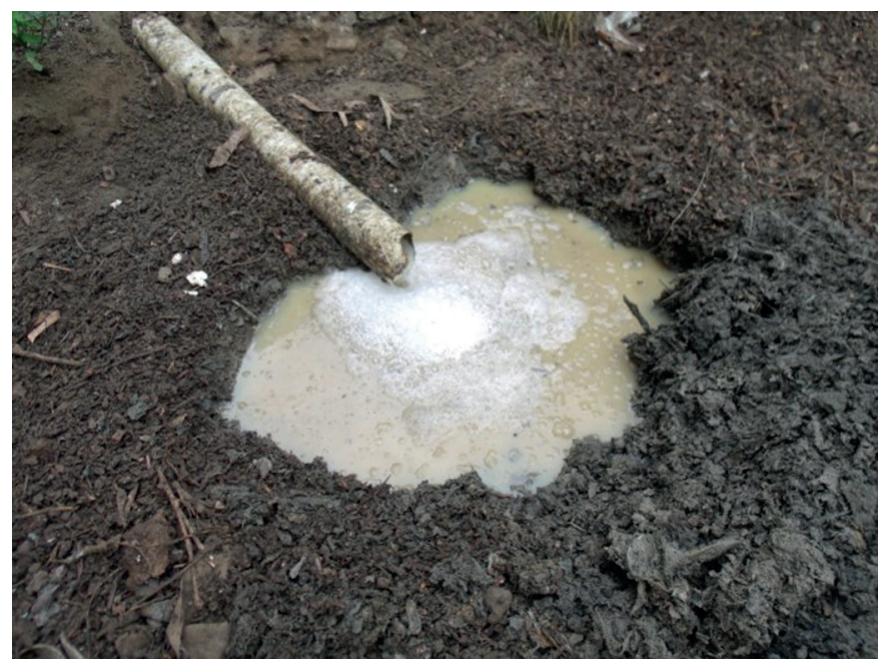

Fig.1. Cassava wastewater being discharged through a pipe to an unprotected area to which animals have access. nohydrin ( $\alpha$-hydroxynitrile). The cyanohydrin can spontaneously decompose into cyanide and ketone above $\mathrm{pH}$ 4 and temperatures above $30^{\circ} \mathrm{C}$ (Montagnac et al. 2009). During the production of cassava flour, there is enzymatic hydrolysis of cyanogenic glycosides with liberation of HCN (Bourdoux et al. 1982, Cagnon et al. 2002), which is solubilized or volatilized during the process (Ikediobi et al. 1993).

The aim of this research was to study the toxicity of cassava wastewater in sheep and the possible loss of toxicity in the period of 1-3 days after production.

\section{MATERIALS AND METHODS}

The experiment was performed at the Universidade Federal do Recôncavo da Bahia and was approved by the University Committee for Animal Experimentation (protocol 23007.013398/201221). The cassava plant cultivated in the region and used in this experiment was identified by Marcio Lacerda Lopes Martins as Manihot esculenta Crantz (Fig.2A). One voucher specimen was registered as HURB 8963 and deposited in the herbarium of the Universidade Federal do Recôncavo da Bahia.

Sample preparation. The cassava wastewater used in the experiment was obtained from a local factory ("casa de farinha") in the municipality of Cruz das Almas (120 40' $12^{\prime \prime} \mathrm{S} 39^{\circ} 06^{\prime} 07^{\prime \prime}$ $0)$, region of Recôncavo da Bahia, northeastern Brazil. At the factory, the bitter cassava (Fig.2B) was subjected to the following process: the tubers were washed, peeled by hand, and ground in an electric grinder. The mash obtained from this procedure was then strongly pressed in a wooden press (Fig.2C); the mass that resulted from the press was immediately crumbled in an electric mill, and lastly toasted in an oven to obtain the flour - a fine, white, granular powder with a peculiar flavor. The wastewater flows during the pressing of the mash. It is slurry with an active odor, beige or yellow color, and is locally known as "manipueira". The amount of wastewater produced was approximately 1 litter per $3 \mathrm{~kg}$ of cassava. The wastewater was stored in an open plastic container (Fig.2D). Immediately after production (time zero) and 24 hours after storage, defined volumes of wastewater were administered to the sheep. Samples were collected at time zero, 24, and 48 hours later for determination of the levels of cyanogenic compounds.

Cyanid quantification. The cyanogenic compounds (free cyanide, $\alpha$-hydroxynitrile, and cyanogenic glycosides), were determined by spectrophotometry $(605 \mathrm{~nm}$ in UV-Visible GENESYS 10S) using the chloramine-T, sodium isonicotinate 1,3 dimethylbarbiturate method (Essers 1994). The hydrolysis of cyanogenic glycosides was used to linamarase purified from the cassava peel (Cooke 1979). The dose to be administered to each sheep was calculated based on the cyanide concentration of the sample in agreement with Cereda (2003).

Picric acid paper test. The paper strips for the picric acid paper test were prepared by immersion in a solution of $5 \mathrm{~g}$ of sodium carbonate and $0.5 \mathrm{~g}$ of picric acid in $100 \mathrm{~mL}$ of distilled water. The intensity of the reaction was determined by the color change of the strip: first from yellow to orange, and later to red brick. The intensity of the reaction was classified as strongly positive (change to red brick within 5 minutes), moderate (change to orange within 5-10 minutes), mild (change to orange between 10 minutes and 3 hours), and negative (no color change) (Tokarnia et al. 2012).

Sheep experiment. Six healthy 3-year-old Santa Inês sheep weighing 38-52 kg were kept in individual stalls, treated with levamisole phosphate, and fed a concentrate diet (Ovinotech Nestlé Purina) at a quantity equivalent to $1 \%$ body weight, and water and hay ad libitum. Before administration of the wastewater, animals 


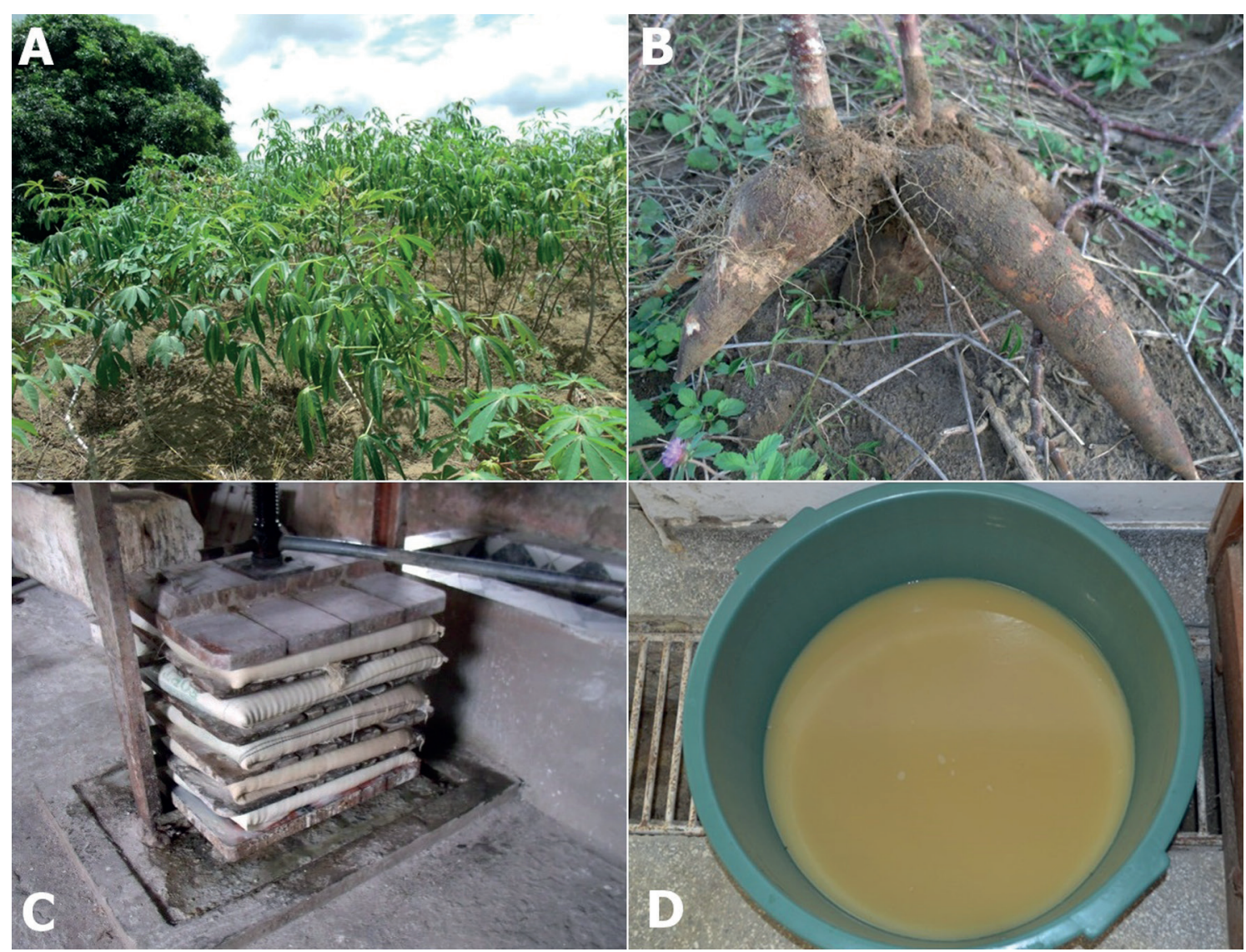

Fig.2. (A) Plants of Manihot esculenta. (B) M. esculenta tubercles. (C) Mash prepared from cassava tubercles conditioned into bags to be pressed. (D) Cassava wastewater used in the experiment, which was obtained from pressing the cassava mash.

were weighed and fasted for 12 hours with water ad libitum. The animals were examined 10 minutes before and 10 minutes after the administration of wastewater for determination of heart and respiratory rates, rectal temperature, and ruminal movements.

The wastewater was administered in single doses to each sheep by oral gavage on the first day of the experiment and 24 hours later. On the first day, sheep 1-6 received respectively: $0.99 \mathrm{mg}$ of HCN kg-1 body weight (624,0 mL), $0.75 \mathrm{mg} \mathrm{kg}^{-1}$ (403,0 mL), 0.70 $\mathrm{mg} \mathrm{kg}^{-1}(509,6 \mathrm{~mL}), 0.63 \mathrm{mg} \mathrm{kg}^{-1}(427,0 \mathrm{~mL}), 0.5 \mathrm{mg} \mathrm{kg}^{-1}(284,0$ $\mathrm{mL})$, and $0.0 \mathrm{mg} \mathrm{kg}^{-1}(500,0 \mathrm{~mL})$. After 24 hours of storage of the wastewater, the doses of cyanogenic compounds administered to sheep 1-6 were respectively: $0.46 \mathrm{mg} \mathrm{HCN} \mathrm{kg}{ }^{-1}, 0.34 \mathrm{mg} \mathrm{kg}^{-1}$, $0.31 \mathrm{mg} \mathrm{kg}^{-1}, 0.28 \mathrm{mg} \mathrm{kg}^{-1}, 0.23 \mathrm{mg} \mathrm{kg}^{-1}$, and $0.0 \mathrm{mg} \mathrm{kg}^{-1}$. The volume of wastewater was the same in both days for sheep 1-5 respectively: $14.2 \mathrm{~mL} \mathrm{~kg}^{-1}, 10.6 \mathrm{~mL} \mathrm{~kg}^{-1}, 9.8 \mathrm{~mL} \mathrm{~kg}^{-1}, 8.89 \mathrm{~mL} \mathrm{~kg}^{-1}$, and $7.1 \mathrm{~mL}$ $\mathrm{kg}^{-1}$. Sheep 6 (control) received $9.8 \mathrm{~mL}$ of water $\mathrm{kg}^{-1}$.

The sheep that showed signs of HCN poisoning were treated with intravenous administration of an aqueous solution with $20 \%$ sodium thiosulfate at a dose of $0.5 \mathrm{~mL} \mathrm{~kg}^{-1}$ (Amorim et al. 2005).

\section{RESULTS}

The cyanogenic compounds concentration of the wastewater, determined by spectrophotometry, decreased rapidly within 48 hours of storage. The cyanogenic compounds concentration in the wastewater was 71.69 $\pm 2.19 \mu \mathrm{g} \mathrm{HCN}$ $\mathrm{mL}^{-1}$ immediately after production, $30.56 \pm 2.45 \mu \mathrm{g} \mathrm{HCN}$ $\mathrm{mL}^{-1}$ after 24 hours, and 24.25 $\pm 1.28 \mu \mathrm{g} \mathrm{HCN} \mathrm{mL} \mathrm{H}^{-1}$ after 48 hours. Similar results were observed with the picric acid paper test (Fig.3 and Table 1).
The experimental reproduction of the disease resulted in clinical signs of poisoning 4-5 minutes after administration of wastewater in the five sheep that received doses with decreasing concentrations of cyanogenic compounds. She-

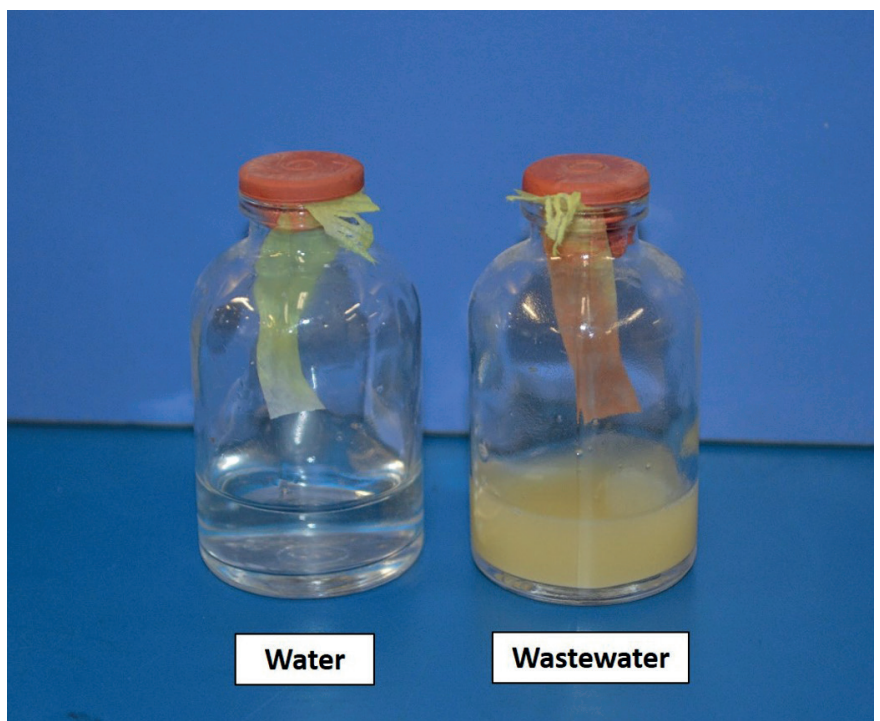

Fig.3. Picric acid paper test performed with the wastewater immediately production. The vial on the right contains wastewater and the change in color to red can be seen (positive) $5 \mathrm{mi}-$ nutes after closing the vial. The paper on the left vial did not change (negative). 
ep 1, 2, and 3 showed severe signs including tachycardia, tachypnea, dilated pupils, drooling, dilated nostrils (Fig.4), engorged episcleral vessels, ataxia, weakness (Fig.5), muscle tremors, ruminal atony and bloat. Sheep 4 and 5, which ingested $0.63 \mathrm{mg} \mathrm{HCN} \mathrm{kg}^{-1}$ and $0.5 \mathrm{mg} \mathrm{HCN} \mathrm{kg}^{-1}$, showed mild clinical signs that included ruminal hypomotility, dilated nostrils, tachycardia, and tachypnea. The five sheep recovered in 10-40 minutes after thiosulfate treatment. On the second day of experiment, only sheep 1 and 2 exhibited clinical signs of tachycardia and tachypnea. Sheep 1 exhibited mild muscle tremors. Sheep 1 and 2 recovered 20 and 17 minutes after application of $20 \%$ sodium thiosulfate, res-

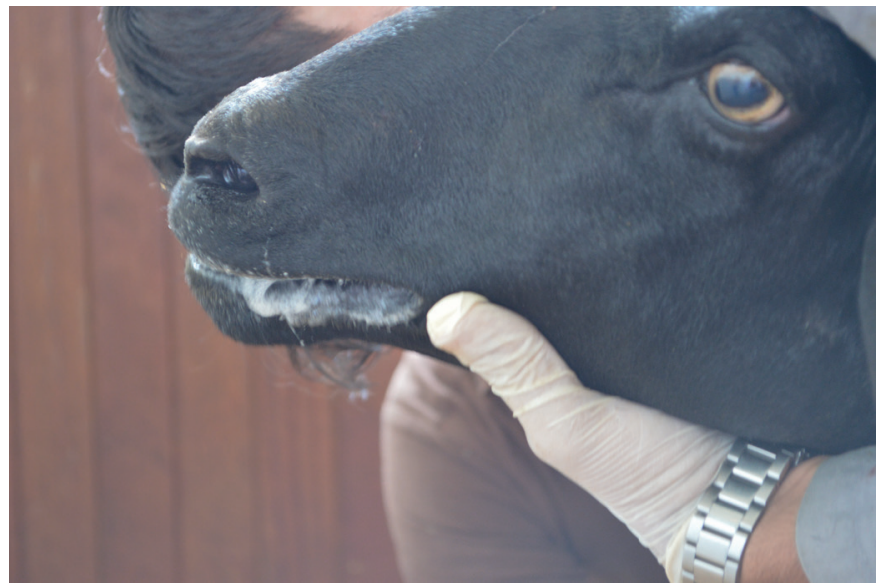

Fig.4. Experimental poisoning by cassava wastewater. Sheep 3 exhibited salivation and dilated nostrils 15 minutes after the ingestion of $0.99 \mathrm{mg} \mathrm{HCN} \mathrm{kg}^{-1} \mathrm{BW}$.

Table 1. Results of the picric acid paper test of the wastewater inmediately after production and 24 and 48 hours after

\begin{tabular}{lccc}
\hline \multirow{2}{*}{$\begin{array}{c}\text { Time after } \\
\text { production (hours) }\end{array}$} & \multicolumn{3}{c}{$\begin{array}{c}\text { Time that was performed and } \\
\text { result of the reaction }\end{array}$} \\
\cline { 2 - 4 } & Start & Orange & Red \\
\hline 0 & $10: 04$ & $10: 08+++$ & $10: 09+++$ \\
24 & $10: 0$ & $10: 11++$ & $10: 15++$ \\
48 & $10: 04$ & $11: 10+$ & -
\end{tabular}

Reaction: +++ acentuated, ++ moderate, + mild, - no reaction.

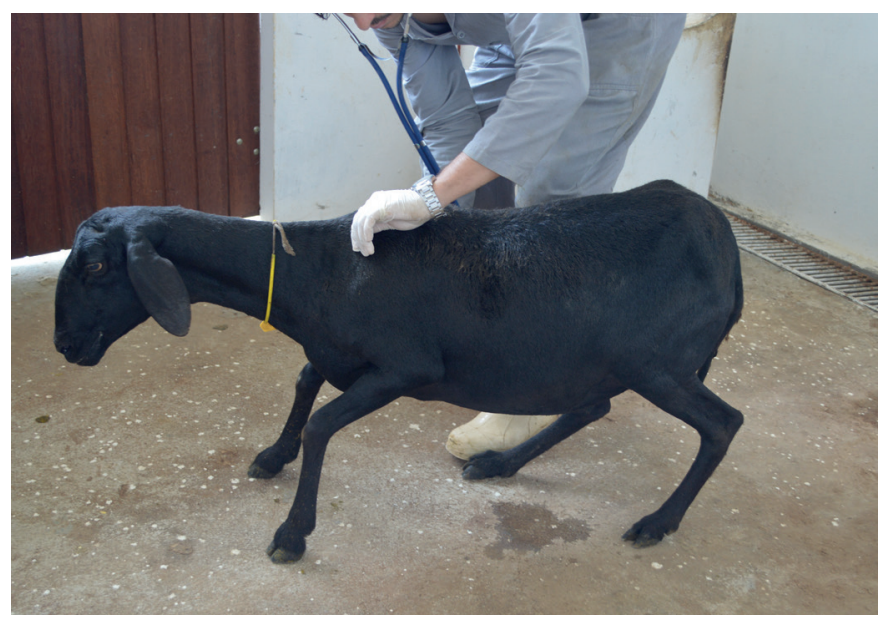

Fig.5. Experimental poisoning by cassava wastewater. Sheep 3 exhibited respiratory distress and flexion (weakness) of the four limbs, 16 minutes after after the ingestion of $0.99 \mathrm{mg} \mathrm{HCN}$ $\mathrm{kg}^{-1}$ BW. y

pectively. Sheep 3, 4, and 5 did not show clinical signs on the second day. Data from the experiment are presented in Table 2 and physiological parameters are presented in Table 3.

\section{DISCUSSION}

Results obtained from field observations and the experimental study demonstrated that wastewater produced during the processing of cassava is highly toxic immediately after production due to high concentrations of cyanogenic compounds $\left(71.69 \pm 2.19 \mu \mathrm{g} \mathrm{HCNmL}^{-1}\right)$. An enzymatic hydrolysis occurs during grounding and pressing of the cassava and $70 \%$ of the linamarin from the roots is removed into the wastewater (Hosel \& Barz 1975). On the other hand, this experiment showed that the toxicity is decreased within the first 24 hours after production, when the cyanogenic compounds concentration was markedly reduced $\left(30.56 \pm 2.45 \mu \mathrm{g} \mathrm{HCN} \mathrm{mL} \mathrm{m}^{-1}\right)$ and caused only mild clinical signs. In addition, clinical signs had a rapid onset of 4-5 minutes after ingestion, probably due to the enzymatic hydrolysis of linimarin, which results in free HCN in the wastewater. When animals are poisoned by ingestion of

Table 2. Results of the administration to experimental sheep of wastewater immediately after production and 24 hours later at different doses

\begin{tabular}{|c|c|c|c|c|c|c|c|}
\hline \multirow[t]{2}{*}{ Sheep \# } & \multirow[t]{2}{*}{ Weight (kg) } & \multirow[t]{2}{*}{ Adminstration } & \multirow{2}{*}{$\begin{array}{l}\text { Start of clinical signs } \\
\text { after administration }\end{array}$} & \multirow{2}{*}{\multicolumn{2}{|c|}{$\frac{\text { Dose }}{\text { mgHCN kg-1 }^{-1}}$}} & \multirow[t]{2}{*}{ Clinical signs } & \multirow{2}{*}{$\begin{array}{c}\text { Recovered after } \\
\text { treatment (minutes) }\end{array}$} \\
\hline & & & & & & & \\
\hline \multirow[t]{2}{*}{1} & 44 & A & $4 \mathrm{~min} 03 \mathrm{sec}$ & 0,99 & 624,0 & Severe & 40 \\
\hline & & B & $9 \min$ & 0,43 & 624,0 & Mild & 20 \\
\hline \multirow[t]{2}{*}{2} & 32 & $\mathrm{~A}$ & $4 \mathrm{~min} 30 \mathrm{sec}$ & 0,75 & 403,0 & Severe & 14 \\
\hline & & B & $10 \mathrm{~min}$ & 0,34 & 403,0 & Mild & 14 \\
\hline \multirow[t]{2}{*}{3} & 52 & A & $6 \min$ & 0,70 & 509,6 & Severe & 25 \\
\hline & & $\mathrm{B}$ & $0 \mathrm{~min}$ & 0,31 & 509,6 & Absent & 0 \\
\hline \multirow[t]{2}{*}{4} & 48 & A & $5 \mathrm{~min}$ & 0,63 & 427,0 & Mild & 14 \\
\hline & & B & $0 \mathrm{~min}$ & 0,28 & 427,0 & Absent & 0 \\
\hline \multirow[t]{2}{*}{5} & 40 & $\mathrm{~A}$ & $5 \mathrm{~min}$ & 0,50 & 284,0 & Mild & 20 \\
\hline & & B & 0 & 0,23 & 248,0 & Absent & 0 \\
\hline \multirow[t]{2}{*}{6} & Control & A & 0 & Water & 500,00 & Absent & 0 \\
\hline & & $\mathrm{B}$ & 0 & Water & 500,0 & Abstent & 0 \\
\hline
\end{tabular}

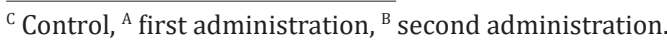


Table 3. Changes in the phisiological parameters of sheep before and after the ingestion of wastewater and on second day

\begin{tabular}{|c|c|c|c|c|c|}
\hline \multirow[t]{2}{*}{$\begin{array}{l}\text { Sheep \#/ } \\
\text { weight }\end{array}$} & & \multirow{2}{*}{$\begin{array}{c}\text { Pulsations } \\
\text { Before/ } \\
\text { after }\end{array}$} & \multirow{2}{*}{$\begin{array}{c}\begin{array}{c}\text { Respiratory } \\
\text { movements }\end{array} \\
\begin{array}{c}\text { Before/ } \\
\text { after }\end{array}\end{array}$} & \multirow{2}{*}{$\begin{array}{c}\begin{array}{c}\text { Ruminal } \\
\text { movements }\end{array} \\
\begin{array}{c}\text { Before/ } \\
\text { after }\end{array} \\
\end{array}$} & \multirow{2}{*}{$\begin{array}{l}\text { Rectal tempe- } \\
\text { rature }\left({ }^{\circ} \mathrm{C}\right) \\
\text { Before/ } \\
\text { after }\end{array}$} \\
\hline & & & & & \\
\hline \multirow[t]{2}{*}{$1 / 44 \mathrm{~kg}$} & Day 1 & $78 / 100$ & $31 / 90$ & $1 / 0$ & $39,2 / 38,6$ \\
\hline & Day 2 & $88 / 99$ & $32 / 32$ & $1 / 1$ & $38,7 / 38,9$ \\
\hline \multirow[t]{2}{*}{$2 / 38 \mathrm{~kg}$} & Day 1 & $80 / 180$ & $21 / 61$ & $1 / 1$ & $38,6 / 38,3$ \\
\hline & Day 2 & $123 / 127$ & $27 / 30$ & $1 / 1$ & $39,6 / 39,5$ \\
\hline \multirow[t]{2}{*}{$3 / 52 \mathrm{~kg}$} & Day 1 & $52 / 130$ & $25 / 70$ & $2 / 0$ & $38,3 / 38,1$ \\
\hline & Day 2 & $78 / 80$ & $32 / 30$ & $2 / 1$ & $39,1 / 38,9$ \\
\hline \multirow[t]{2}{*}{$4 / 48 \mathrm{~kg}$} & Day 1 & $67 / 137$ & $30 / 70$ & $2 / 0$ & $38,3 / 38,5$ \\
\hline & Day 2 & $70 / 77$ & $26 / 34$ & $2 / 2$ & $39,0 / 39,4$ \\
\hline \multirow[t]{2}{*}{$5 / 40 \mathrm{~kg}$} & Day 1 & $90 / 160$ & $22 / 50$ & $2 / 0$ & $39,2 / 38,7$ \\
\hline & Day 2 & $80 / 64$ & $36 / 23$ & $3 / 2$ & $38,7 / 38,8$ \\
\hline \multirow[t]{2}{*}{$6 \mathrm{C} / 31 \mathrm{~kg}$} & Day 1 & $63 / 75$ & $13 / 15$ & $1 / 1$ & $39,1 / 39,2$ \\
\hline & Day 2 & $63 / 75$ & $15 / 14$ & $1 / 1$ & $39,1 / 39,3$ \\
\hline
\end{tabular}

$\overline{{ }^{\mathrm{C}} \text { Control sheep. }}$

Manihot spp., the linamarin is hydrolyzed during digestion and clinical signs appear approximately 20 minutes after ingestion of the plant (Amorim et al. 2005).

In this experiment, the cyanogenic compounds concentration of the wastewater was determined by spectrophotometry and was also estimated by the use of picric acid paper test, with a very good correspondence between the two methods. With high cyanogenic compounds concentrations $\left(71.69 \pm 2.19 \mu \mathrm{g} \mathrm{HCNmL}^{-1}\right)$, the picric acid paper test was strongly positive; it was moderately positive 24 hours after production with $30.56 \pm 2.45 \mu \mathrm{g} \mathrm{HCN} \mathrm{mL}^{-1}$ and less toxicity; and negative 48 hours after production with $24.25 \pm 1.28 \mu \mathrm{g}$ $\mathrm{HCN} \mathrm{mL}{ }^{-1}$. These results suggest that the picric acid paper test is a useful tool to estimate the toxicity of cassava wastewater.

The rapid loss of toxicity of the wastewater and the possibility of using the picric acid paper test to estimate levels of HCN suggest that this product may be used as animal food without risk of poisoning if kept stored for at least 48 hours after production. Cassava wastewater has been used in animal feeding 15 days after its production by administration of $400-1000 \mathrm{~mL}$ daily during 70 days without signs of poisoning (Almeida et al. 2009). With the use of the picric acid paper test to establish the loss of toxicity on the first 2-3 days after production, it is possible to begin the administration of cassava wastewater in a shorter period of time diminishing the need of large reservoirs to keep the product for up to 15 days. Because cassava wastewater is considered an environmental polluter, its use as animal food is also a good way to avoid environmental damage. Each ton of cassava processed to produce flour produces between 267 to $419 \mathrm{~L}$ of wastewater, which may infiltrate the soil and contaminate groundwater and aquifers (Cereda 1994). A ton of cassava processed per day by a starch manufacturer produces a daily pollution equivalent to the pollution caused by 200-300 people, and the production of a ton of cassava for flour causes pollution comparable to the pollution caused by a population of 150-250 inhabitants (Fioretto 2001).
Treatment of the sheep poisoned by the wastewater with $0.5 \mathrm{~mL}$ of sodium thiosulfate per $\mathrm{kg}$ of body weight in a $20 \%$ solution was effective and the animals recovered in 10 to 40 min after the intravenous injection. Thus, it is recommended that the farmers have access to this treatment in cases of poisoning. Another possibility is to treat the animals orally with $250 \mathrm{~g}$ of sodium thiosulfate diluted in $1 \mathrm{~L}$ of water (Riet-Correa et al. 2011). The problem with both treatments is that the disease has a very short period of clinical manifestations before it progresses to death, which makes it difficult to detect poisoning and treat the animals before death.

In northeastern Brazil, poisoning by the cassava wastewater should be differentiated from poisoning by various cyanogenic plants that occur in the region such as Manihot spp., Anadenanthera colubrina var. cebil, Piptadenia viridiflora, Cnidoscolus quercifolius, and Sorghum halepense, and also from monofluoroacetate containing-plants such as Palicourea aeneofusca, P. marcgravii, Amorimia rigida, and Amorimia septentrionalis (Riet-Correa et al. 2011). Because of the similar clinical signs and the short period of clinical manifestation, the only way to make a differential diagnosis when there is consumption of cassava wastewater and presence of these plants is with evidence of consumption of plants by the animals.

The findings of this study demonstrate that cassava wastewater is highly toxic to sheep when ingested immediately after production due to high concentrations of cyanogenic compounds $\left(71.69 \pm 2.19 \mu \mathrm{g} \mathrm{HCNmL}^{-1}\right)$, with dose from $0.70 \mathrm{mgHCN} \mathrm{kg}^{-1}$, but rapidly loses its toxicity in $24-48$ hours. The toxicity of cassava wastewater can be estimated by the picric acid paper test and the wastewater may be used as ruminant food after it loses its toxicity.

Acknowledgements.- This research was financially suported by the National Institute for Science and Technology for the Control of Plant Poisoning /CNPq (Grant no. 573534/2008-0).

\section{REFERENCES}

Almeida S.R.M., Silva A.M., Lima J.P., Almeida A.M.M., Zacharias F. \& Regis U.O. 2009. Avaliação do potencial nutritivo da manipueira na dieta de ovinos deslanados. VI Congresso Brasileiro de Agroecologia, II Congresso Latino Americano de Agroecologia, Curitiba, PR, p.1689-1693. (Abstract)

Amorim S.L., Medeiros R.M.T. \& Riet-Correa F. 2005. Intoxicação experimental por Manihot glaziovii (Euphobiaceae) em caprinos. Pesq. Vet. Bras. 25:179-187.

Bourdoux P., Seghers P., Mafuta M., Vanderpas J., Vanderpas-Rivera M., Delange F. \& Ermans A.M. 1982. Cassava Products: HCN content and detoxification processes, p.100. In: Delange F., Iteke F.B. \& Ermans A.M. (Eds.), Nutritional factors involved in the goitrogenic action of cassava. IDRC, Ottawa.

Cagnon J.R., Cereda M.P. \& Pantarotto S. 2002. Glicosídeos cianogênicos da cassava: biossíntese, distribuição, destoxificação e métodos de dosage, p.83-99. In: Cereda M.P. (Ed.), Culturas de Tuberosas Amiláceas Latino-Americanas. Fundação Cargill, São Paulo.

Cereda M.P. 1994. Resíduos da industrialização da mandioca no Brasil. Editora Paulicéia, São Paulo. 174p.

Cereda M.P. 2001. Manejo, uso e tratamento de subprodutos da industrialização da mandioca. Fundação Cargill, São Paulo. 320p.

Cereda M.P. 2003. Processamento da mandioca como mecanismo de deto- 
xificação, p.47-81. In: Cereda M.P. \& Vilpoux O.F. (Eds), Tecnologia, usos e potencialidades de tuberosos amilacias. Fundação Cargill, São Paulo.

Cooke R.D. 1979. Enzymatic assay for determining the cyanide content of cassava and cassava products. CIAT, Cali. 14p.

Essers A.J.A. 1994. Further improving the enzymic assay for cyanogens in cassava products. Acta Horticultura. 375:97-104.

Ferreira W.A., Botelho S.M., Cardoso E.M.R. \& Poltronieri M.C. 2001. Manipueira: um adubo orgânico em potencial. Embrapa Amazônia Oriental, Belém. 21p.

Fioretto R.A. 2001. Uso direto da manipueira em fertirrigação, p.67-69. In: Cereda M.P. (Ed.), Manejo, uso e tratamento de subprodutos da industrialização da mandioca, Fundação Cargill, São Paulo.

Hosel W. \& Barz W. 1975. B-glucosidases from Cicer arientum L. Eur. J. Biochem. 57:607-616.

Ikediobi C.D., Ibrahim S. \& Ogbonna A. 1993. Linamarase from Fusarium esquisiti. Appl. Microbiol. Biotechnol. 25:327-333.
Montagnac J.C., Davis C.R. \& Tanumihardjo S.A. 2009. A processing techniques to reduce toxicity and antinutrients of cassava for use as a staple food. Compr. Rev. Food Sci. Food Saf. 8:17-27.

Murugesrawi R., Balakrishnan V. \& Vijayakumar R. 2006. Studies to assess the suitable conservation method for tapioca leaves for effective utilization by ruminants. Livest. Res. Rural Dev. 18(3).

Pinheiro E.E.G., Oliveira R.S., Silva R.M.M., Santos M.C., Macêdo J.T.S.A. \& Pedroso P.M.O. 2013. Plantas tóxicas para animais de produção no Recôncavo da Bahia. XL Congresso Brasileiro de Medicina Veterinária, Salvador, BA, p.1. (Abstract)

Riet-Correa F., Bezerra C.W.C. \& Medeiros R.M.T. 2011. Plantas Tóxicas do Nordeste. Sociedade Vicente Palloti, Santa Maria. 82p.

Tokarnia C.H., Brito M.F., Barbosa J.D., Peixoto P.V. \& Döbereiner J. 2012. Plantas Tóxicas do Brasil para Animais de Produção. Editora Helianthus, Rio de Janeiro. 566p. 